\title{
FUNCTIONAL VARIABILITY OF THE REVIEW GENRE IN MODERN UKRAINIAN MEDIA COMMUNICATION
}

\author{
Larysa SHULINOVA, Dmytro DERGACH \\ Kyiv National Taras Shevchenko University, Ukraine \\ E-mail: shulinova.lesja@gmail.com; dimyla_philolog@ukr.net
}

\begin{abstract}
The article is devoted to the linguistic and stylistic solution to research problems of communicative variance of the review genre in modern Ukrainian mass media. The author's provability is based on the contrast of the chosen methodology of medialinguistic analysis and the already formed tradition in the social and communicative scientific paradigm. It allows to realize a comprehensive, syncretic investigation of the functional, context-oriented nature of the review. Medialinguistic analysis of the review genre is based on current illustrative material from authoritative in Ukraine media resources (Voice of America, Radio Free Europe / Radio Liberty, BBC) that were interpreted using stylistic and quantitative methodology. It helps to indicate the permanent evolution of the review model: architectonics, system of language units and most importantly - functions. There is a tendency for the review to be more informative, and its analytical nature is defined as an additional functional component a priori. Thus, the idea of the review hypergenre status, alternatively realized in the style of mass media communication, is argued in connection with its extralinguistically motivated tasks and priorities. Such peculiarity of the review genre helps to determine the prospects of its research analysis, especially nowadays, in linguistic and cultural discourse that deepens the medialinguistic and genre subjectivity of the professional interpretation of modern mass media communication.
\end{abstract}

KEYWORDS: genre, genre theory, review, media, medialinguistics, media analytics, media information, language function, Ukrainian language.

Introduction. The modern media sphere with its increasing focus on pragmatic communicative demands of the mass audience is actively creating new research fields with a set of issues that need a scientific solution. Thus, the linguistic subjectivity of professional media analysis is based on the use of linguistic factology in connection with proving the functional and stylistic nature of media texts. Today the actual linguistic context of such observations seems quite descriptive and static. Thus, the problem area of genre interpretation of media is outlined, where genre is a category that summarizes the language resource, communicative tasks and functional potential of the text as a unit of communication. "Verbal and symbolic design of a typical situation of social interaction of people" (Sedov, 2012, p. 216). That is why there are often difficulties in genre identification of media texts, which, due to the geolinguistic openness of the media, are dialogic / polylogical in their genre status, and even more ambiguity and variability in the analysis of communicative dynamics of the media sphere."A journalistic text is a structurally and systemically organized, communicative, iconic unit, which is a holistic and complete message, functioning in the field of mass communication, reflecting social issues" (Kozhakhmetova, Ospanova, Mussatayeva, Bissenbayeva, 2020). Hence, nowadays a variety of interpratations of the functional and typological nature of the genres of news, advertising, media article, review, show, etc is current and actual.

The most revealing in this case is the discussion of the functional syncretism of information and analytical genres of media communication and their research identification. Thus, news in media linguistics is analyzed in the discourse of a multiple genre paradigm. Being hourly, daily news or typological format breaking news is a classic information content, which at the level of semantic, architectural organization of the text and the appropriate selection of language units involves their own information, without delving into interpretation and reflection. In turn, weekly or annual news is aimed at summarizing and analyzing precedent events that have a public resonance. Consequently, their analytical function is in some way complemented by the effectiveness of manipulating selection of precisely those news items that, according to a media source, will support its rating and have a productive impact on the mass language consciousness. So, scientists have persuasive reasons to "define media power first of all in terms of social power of groups and institutions... Given the rule of intentions, purposes, and goals in the definition of action, however, action control presupposes mind control. This is the essence of the persuasive social power, and typical of the power of the media and other types of public discourse. The traditional study of media "effects", thus, needs to be reformulated in terms of cognitive processes and representations. A socially oriented cognitive science 
provides insight into these structures and strategies of cognition, and hence offers a foundation for a new understanding of the persuasive power of the media“" (Dijk, 1995, p. 31). Such a research problem and methodological options for its solution actualize the debatable nature of the linguistic stylistics of the review genre - the object of professional interpretation in the article. The subject is the stylistic specificity of the review, its architectonics and language dominants in connection with the dynamics and variability of the common form of media communication. It confirms the thesis that in addressing „genre, textual and discursive analysis, narrative and other formats issues a structural and semiological analysis of hidden meanings plays the leading role" (McQuail, 2010, p. 304).

Aspectology of the review analysis in scientific discourse. The tradition of review interpretation was formed in various publications of researchers from different fields of scientific knowledge - linguistic stylistics, communicative studies, medialinguistics, science of social communications. Thus, in the late 20th and early 21 st centuries, the research position regarding the review as a secondary genre of analytical nature was outlined that provides for the semantic generalization of information, verbalization of assessment of facts.

In particular, the authoritative lexicographic context of understanding the genre characteristics focuses on the fact that the review is:

$\checkmark$ "a report in a newspaper, magazine, or programme that gives an opinion about a new book, film, etc.; a (part of a) newspaper or magazine that has articles on films, books, travel, famous people, etc." (Cambridge dictionary);

$\checkmark$ "a critical appraisal of a book, play, film, etc. published in a newspaper or magazine; a periodical publication with critical articles on culture and current events" (Oxford dictionary);

$\checkmark$ "a report in the media in which someone gives their opinion of something such as a new book or film" (Collins dictionary).

Medialinguistic subjectivity of the analysis takes into account that ,a review is an analytical genre of media, the main feature of which is the unity of coverage of social events and in-depth analysis of the essence of the process. The position of the columnist (media worker) is clearly revealed in the review. It should arouse the interest of the audience, tell it about events, processes taking place in public life, defend the advanced views and help to improve the „personal strategy“ of citizens, reveal phenomena and their essence, show the contradictions of reality and others. By clarifying the essential connections, defining the line of development of phenomena, understanding the trends of social development and promoting the problems of society, the reviewer should create a quality review media work, in which the main emphasis will be on a detailed description and analysis of politics, economics, education, culture. The main method of the review is to acquaint the audience with the important for the society processes taking place today by means of in-depth consideration of a certain set of facts, united by time, space, ideas, relevant to society" (Shevchenko, Dergach, Syzonov, 2014, p. 128-129).Linguopragmatics of media communication assumes that:

$\checkmark$ "a review is a critical evaluation of a text, event, object, or phenomenon... it makes an argument... it should develop the thesis in a logical manner... The most important element of a review is that it is a commentary, not merely a summary. It allows you to enter into dialogue and discussion with the work's creator and with other audiences. You can offer agreement or disagreement and identify where you find the work exemplary or deficient in its knowledge, judgments, or organization. You should clearly state your opinion of the work in question, and that statement will probably resemble other types of academic writing, with a thesis statement, supporting body paragraphs, and a conclusion... So, a review gives the reader a concise summary of the content; a review offers a critical assessment of the content; a review often suggests whether or not the audience would appreciate it" (Book reviews).

$\checkmark$ "writing reviews is a great way to keep abreast of developments and trends in one's own discipline" (Fleenor, 2004, p. 1036 - 1037).

The genrology tradition takes into account that the reviews:

$\checkmark$ "are not usually categorized them according to the final recommendation given by the reviewers. There have been a few exceptions, however. One is Gosden's (2003) study of two groups of reviews, those with the outcomes of "accept with revisions" and "unacceptable". The two sets of reviews are shown to differ in the categories of reviewer comments found in them, and the reviewer comments given to the "accept with revisions" reviews were said to be more helpful for authors 
making revisions. Reviews with different outcomes have also been shown to result in the construction of different reviewer roles..." (Samraj, 2016);

$\checkmark$ "are the summary of current state of understanding on a particular research topic. They analyze or discuss research previously published by scientists and academicians rather than reporting novel research results. The review articles come in the form of systematic reviews and literature reviews and are a form of secondary literature. Systematic reviews determine an objective list of criteria, and find all previously published original research papers that meet the criteria. Then they compare the results presented in these papers. Literature reviews, by contrast, provide a summary of what the authors believe are the best and the most relevant prior publications" (Mass media review articles);

$\checkmark$ "are vehicle not only for informing an audience of a book's or media production's merits but also for entertaining and occasionally provoking that same audience" (Ventres, Morrow, 2009).

Methodology of analysis. Research ambivalence is in use of both descriptive (ascertaining, non-dialectical) and a group of analytical (interpretive, dialectical) methods. In general, it allows to realize a comprehensive, syncretic investigation of the functional, context-oriented nature of a particular object. And formulated subjectivity, in turn, is based on the relevance of medialinguistic studies in this field. Media studies has shifted its emphasis away from text analysis to audience reception ... tends to be a monolithic view of the role of media in ideological reproduction which understates the extent of diversity and change in media practices and media discourse (Fairclough, 1995, p. 29). Discursive analysis of the review is connected with understanding of discourse as a "holistic speech product in the diversity of its cognitive-communicative functions" (Sedov, 2012, p. 217). Thus, the descriptive method is designed to a greater extent on the statement, linear, scientific qualification of review as a relevant principle of informing in media. The scientific orientation of the research is deepened by using the method of functional and stylistic analysis - for the reasoned solution of debatable issues about syncretism / dominancy of review information and analytical functions, verbalized in stylistic categories of different nature. The method of content analysis is based on a continuous sample of the review texts in Ukrainian sources of illustrative material - Voice of America (VOA), Radio Free Europe / Radio Liberty, BBC (2020). It allowed to determine thematic groups and classify analyzed reviews. And with the help of quantitative calculations - schematically to illustrate proposed stratification in figures and tables, which, of course, enhance the evidence of the study.

Linguostylistics of the review in modern Internet media. For the investigation of the functional variability of the review genre in modern Internet media we have brought texts, published in the media resources of the Voice of America ${ }^{1}$, Radio Free Europe / Radio Liberty and BBC ${ }^{3}$, aimed at broadcasting in Ukraine in 2020. According to various criteria, such as: genre features, architectonics and determination of the text's affiliation to the review by media authors, we have identified 442 sources (including 222 - in Voice of America Ukraine, 160 - in Radio Liberty, 60 - in BBC NEWS Ukraine).

\footnotetext{
${ }^{1}$ https://ukrainian.voanews.com

${ }^{2}$ https: //www.radiosvoboda.org

${ }^{3}$ https://www.bbc.com/ukrainian
} 


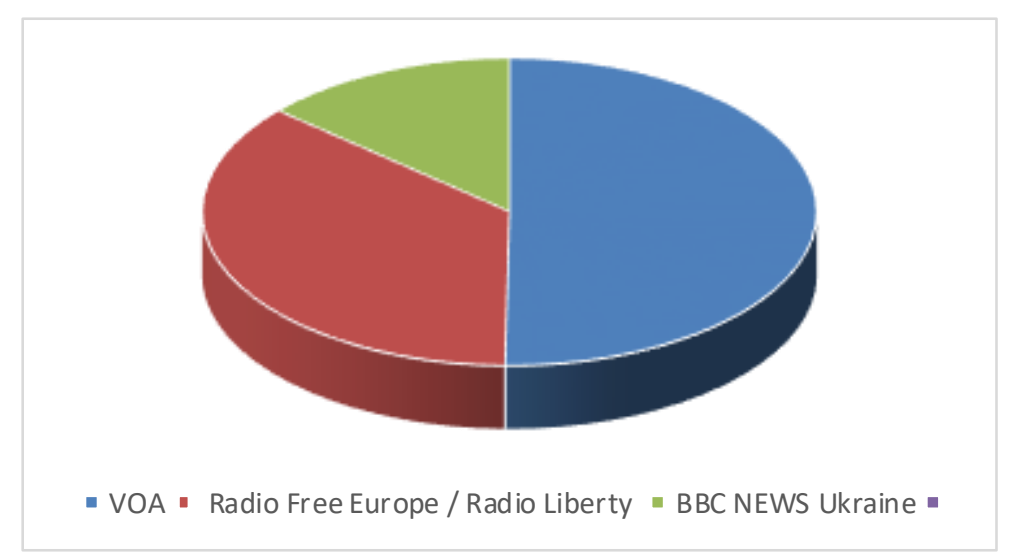

Fig. 1. The Reviews

The reviews also included those creolized texts that the search systems of the considered media resources submit upon the request "review".

Topics and genre models of reviews differ both within one and different media resources.

Voice of America (VOA) "is the largest international news broadcaster in the United States. The Voice of America speaks 45 languages to people who do not have full or complete access to a free press. Since its inception in 1942, the Voice of America has been committed to comprehensive and independent coverage and truth-telling"4. The Ukrainian department was established in November 1949 (Sukhobokova, 2009, p. 61). "The mission and editorial independence of the Voice of America is guaranteed by laws that protect VOA journalists from the influence, pressure or retaliation of government officials or politicians. In 1976 President Gerald R. Ford signed the Voice of America Act that states:

1. VOA will serve as a consistently reliable and authoritative source of news. VOA news will be accurate, objective and comprehensive.

2. VOA will represent the whole America, not a separate segment of American society, and will therefore represent significant American views and institutions in a balanced and comprehensive way.

3. VOA will represent United States policy clearly and effectively, as well as a responsible discussion and opinion on that policy.

In 1994 the US Congress passed the International Broadcasting Act. This law requires that the work of Voice of America journalists must be authoritative, accurate, objective, comprehensive, balanced and reflect the cultural and social diversity of the United States.In 2016, under the State Protection Act, the Congress reaffirmed that the function of collecting and disseminating information

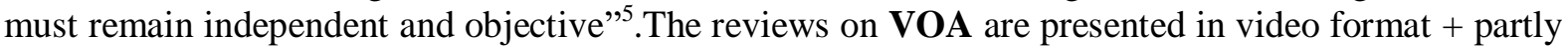
in text - as an announcement or a summary. 17 reviews of US news over the weekend, 3 reviews of news from the US, 65 - with the title "Main about COVID-19", 6 - about world events, 5 reviews of expert opinions on various issues (including impeachment, falling prices, international events), $6-$ various topics. We observe a tendency to prioritize presentation of information and analytical content about the United States or from the point of view of the US media and experts on events (domestic, international and in Ukraine). It is also limited reviews of foreign media resource. Reviews include the information program "Time" (121 episodes) "about world events, life in America and AmericanUkrainian relations" $"$, because it is actually an overview of the events of the day.

\footnotetext{
${ }^{4}$ https://ukrainian.voanews.com/p/5206.html (26 July 2020)

5 https://ukrainian.voanews.com/p/5206.html (26th July 2020)

${ }^{6}$ https://ukrainian.voanews.com/a/5232950.html (27th July 2020)
} 


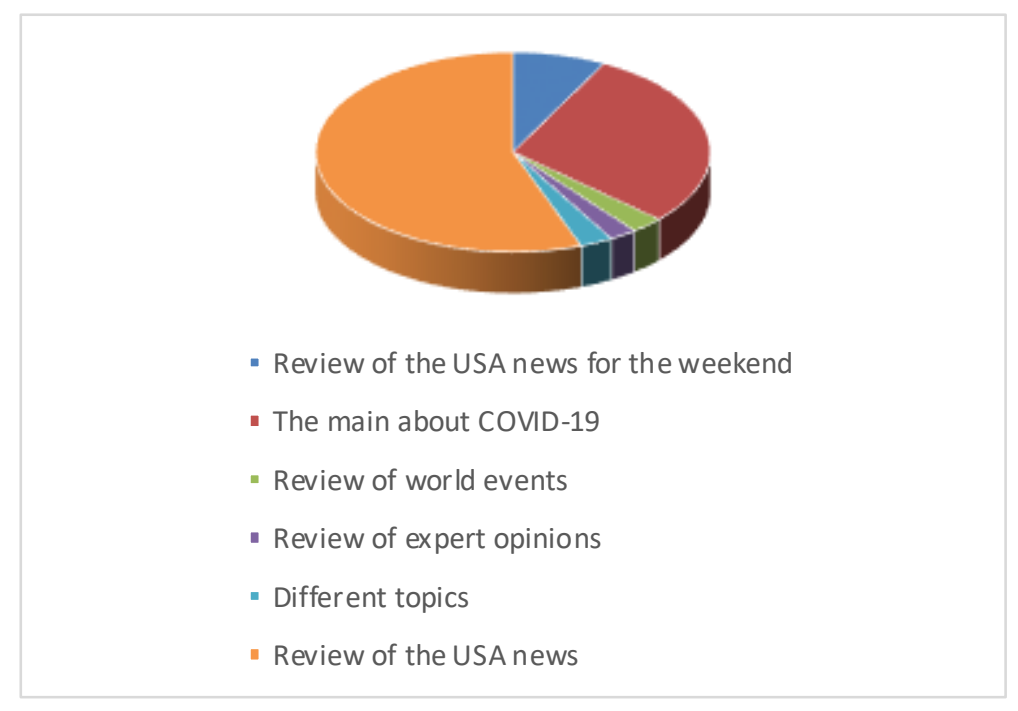

Fig. 2. The Reviews. Voice of America

Radio Liberty Ukraine. Radio Liberty generally positions itself as the Radio Free Europe / Radio Liberty (RFE / RL) - an independent media corporation funded by the US Congress grants provided through the U.S. Agency for Global Media (USAGM). RFE / RL is governed by U.S. law to provide an accurate, objective, and professional journalism product to its audience. U.S. government officials, including USAGM management, are prohibited from interfering in the journalistic reporting of RFE / RL. The Ukrainian edition of Radio Liberty has existed since 19547. Radio Liberty sees its mission "in promoting of democratic values and institutions by addressing the audience of those countries, where freedom of the press is restricted by the authorities or has not yet become the norm in public life. Radio Liberty journalists provide their audiences with information that is not available to them from the local media: uncensored news, exchange of views, open discussion of problems" ${ }^{\prime 8}$.It should be noted at once that this media resource is characterized by rubrication of the reviews according to the various criteria, including topics (politics, economics, society, culture, etc.) and genre affiliation (press review, international press review), according to which 96 texts - are reviews of political topics from domestic Ukrainian information resources, 31 - political reviews of the international press, 5 - posted in the section "Society", 2 - "Culture", 1 - "Economy", 19 - about situations, events, related to COVID-19 (including coverage of the situation, regarding the coronavirus in the world - 10,9-Ukraine's internal problems with coronavirus). The obvious focus of the media resource policy is to cover mostly internal issues of Ukraine - more than $50 \%$ of the texts.

\footnotetext{
${ }^{7} \mathrm{https} / / /$ www.radiosvoboda.org/p/4388.html (29 $9^{\text {th }}$ July 2020)

${ }^{8}$ https://www.radiosvoboda.org/p/4388.html (29 ${ }^{\text {th }}$ July 2020)
} 


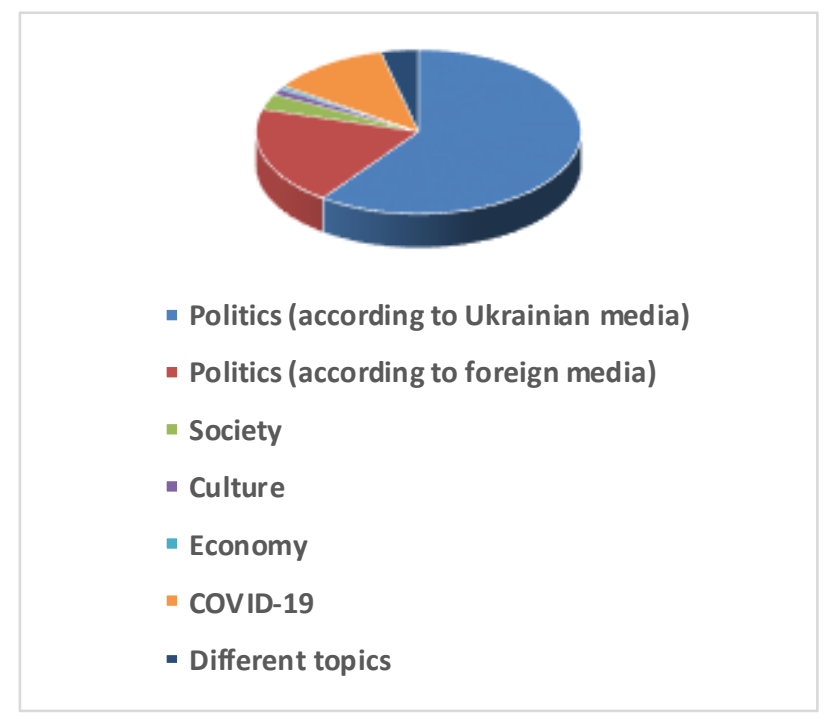

Fig. 3. The Reviews. Radio „Liberty“

BBC NEWS Ukraine. BBC Ukraine is the website of the Ukrainian Service of the British Broadcasting Corporation. It shares "the basic principles of the corporation's work, including accuracy, impartiality in the coverage of events" .

"The BBC's mission is to act in the public interest, to satisfy the interests of our entire audience by providing unbiased, high-quality and original materials and services that inform, educate and entertain" 10 .

"The Ukrainian service of BBC began broadcasting on June 1, 1992 (after the collapse of the Soviet Union) and stopped it on April 29, 2011, remaining only in Internet at bbc.ua.

bbc.ua - British and Ukrainian version of coverage of Ukrainian and world events in the Internet, page of the Ukrainian service of the BBC. The structure of the main portal has the following sections: News, Details, Life, Multimedia, Forum. These pages also have their own permanent headings: "Ukraine", "World" (these two headings cover the analysis of current events in Ukraine and the world), "Business", "Culture and Society", "Press", "Learning English" (heading for English language learners), "Weather".

Note that the official website bbc.ua defines the genre specifics of the review: "Review material, based on a critical assessment of the event, work of art, etc., which contains first-hand opinion" $"$.

This media resource presents only three types of reviews - (1) review of the press as the title of a separate section and texts in it, (2) review of Western media on a variety of topics, (3) cultural review.

Two groups in total organize 50 texts of different topics (29), but some of them are united around one generalized theme, in particular, „Coronavirus“ (14 texts) and politics ( 7 texts). Cultural review - 10 texts. It should be noted that authors of the media resource marked the texts on the relevant topics and genres in the title - "Cultural review", "Press review" and "Western Mass Media". We clearly trace the focus on acquainting recipients with current, important and interesting events, situations, problems in today's globalized world without focusing on information only locally oriented - for a particular country.

\footnotetext{
9 https://www.bbc.com/ukrainian/institutional-38144833 (25 $5^{\text {th }}$ July 2020)

${ }^{10} \mathrm{https}: / /$ www.bbc.com/ukrainian/institutional-50170368 (25 July 2020)

${ }^{11}$ https://www.bbc.com/ukrainian/institutional -50170368 (25 ${ }^{\text {th }}$ July 2020) 


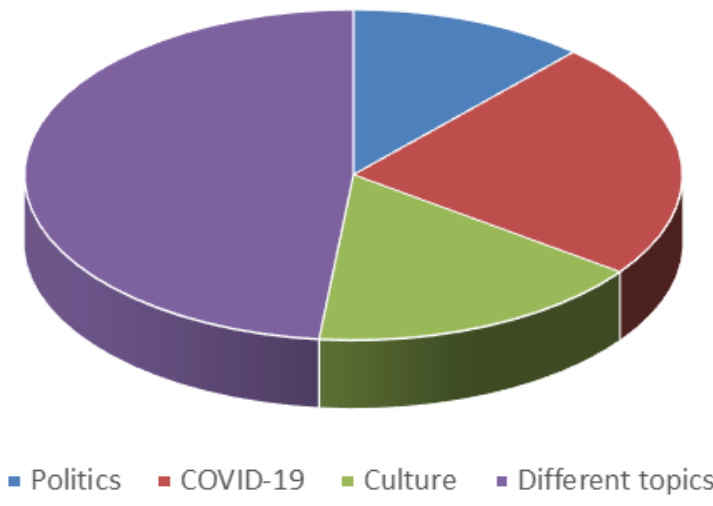

Fig. 4. The Reviews. BBC NEWS Ukraine

$\begin{array}{lccc}\begin{array}{l}\text { Rubrication / } \\ \text { Topic }\end{array} & \text { VOA } & \begin{array}{l}\text { Radio Liberty } \\ \text { Ukraine }\end{array} & \begin{array}{l}\text { BBC NEWS } \\ \text { Ukraine }\end{array} \\ \begin{array}{l}\text { Different topics } \\ \text { Political review }\end{array} & + & + & + \\ \text { Review of foreign media } & + & + & + \\ \text { Review about COVID-19 } & & + & + \\ \text { Review of cultural events and phenomena } & & + & + \\ \text { Review of expert opinions } & + & + & + \\ \text { Review of social events } & & + & + \\ \begin{array}{l}\text { Economic review } \\ \text { Review of world events }\end{array} & + & + & + \\ \text { Review of the USA news for the weekend } & + & + & + \\ \text { Review of news from the USA } & + & \\ \text { Review of Ukrainian media } & & \end{array}$

Table 1. Summary table of analyzed sources

The genre model in the researched reviews in VOA, Radio Liberty Ukraine, BBC NEWS Ukraine is variable, depending on the media resource, but within each of them there is a typical one. And therefore, “...text as multifunctional, always simultaneously representing the world (ideational function) and enacting social relations and identities (interpersonal function); seeing texts as built out of choices from within available systems of options in vocabulary, grammar, and so forth. Discourse is seen as 'a field of both ideological processes and linguistic processes, and . . . there is a determinate relation between these two kinds of process'; specifically, linguistic choices that are made in texts can carry ideological meaning..." (Fairclough, 1995, p. 25).

Let`s prove it by considering in more details.

VOA

1. One model of the news review is dominant - the title that indicates the genre affiliation, in particular recurring: „Огляд головних новин у США за вихідні. Відео“, „Огляд подій у США за вихідні. Відео“, „Не пропустіть: огляд головних новин із США“, or single-, multi-component (by displayed events) „Головне про коронавірус. 24 березня “12, „Час-Тайм. Резонансні події та заяви з Мюнхенської конференції“13, „Огляд новин у США: у Білому домі вирішують, коли відкривати економіку; кількість безробітних зростає. Відео “14.

„Екстремальна погода, зменшення кількості нових хворих на соvid-19 у Нью-Йорку та інше у огляді важливих новин. Відео "15. The video, structured according to the covered events

\footnotetext{
${ }^{12}$ https://ukrainian.voanews.com/a/khronika-covid-24-bereznia/5343307.html (3 ${ }^{\text {rd }}$ August 2020)

13 https://ukrainian.voanews.com/a/5290698.html ( $3^{\text {rd }}$ August 2020)

$14 \mathrm{https}$ ://ukrainian.voanews.com/a/american-weekend-news-overview/5251805.html (4 ${ }^{\text {th }}$ August 2020)

15 https://ukrainian.voanews.com/a/us-news-development-pandemic/5370316.html (3 ${ }^{\text {rd }}$ August 2020)
} 
(it starts literally according to what is indicated in the title or descriptively after the event), there is no concluding or generalizing part, the authors of the stories also have no comments. Under the video the titles of structural and semantic components can be given, for example: „Білий Дім оголив імена юристів, які захищатимуть Дональда Трампа під час розгляду справи про його імпічмент в Сенаті // Штат Вірджинія готується до масових та потенційно небезпечних демонстрацій, які заплановані у понеділок // У США стартує національний перепис населення, який проводять раз на 10 років//"16 or the main semantic accents of the video review, which can be conditionally considered as a concluding and generalizing part: „На прес-конференції з нагоди річничі журналісти не отримали багато конкретних відповідей на свої питання. Але, втім, почули, що президент Зеленський думає про другий термін “ („Прес-конференція президента Украйни - огляд заяв. Відео“"17).

Schematically this model can be represented in such a way:

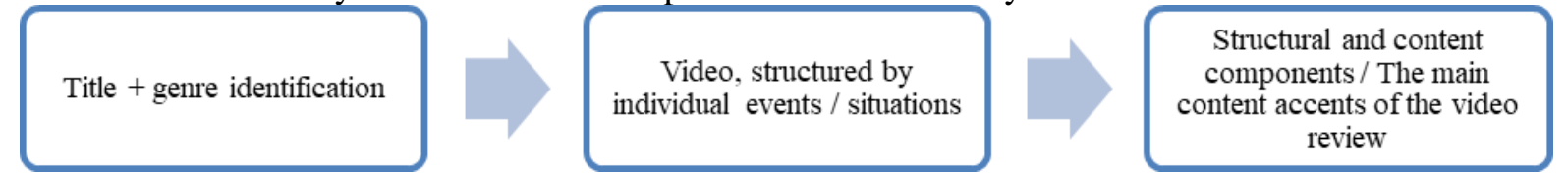

2. The reviews, in particular about the COVID-19, have a different model, because they can be presented in text format with creolization through photos, hyperlinks to media resources of information, tweets, videos. Like „Головне про коронавірус. 12 квітня " ${ }^{8}$, further as a subtitle one of informational reasons: „Християни західного обряду святкують Великдень в умовах коронавірусу й Папа Римський Франциск скасував традииійну месу на площі Святого Петра“".

Photo with caption „Зазвичай переповнена на Великдень площа Святого Петра у Ватикані закрита для відвідувачів, поки Папа Римський звертається до вірян віртуально, 12 квітня 2020 (REUTERS/Guglielmo Mangiapane) “.

Structural part "The most important":

- $\quad$ В Україні зафіксували 266 нових випадків коронавірусу, повідомило МОЗ. Станом ранок на 12 квітня виявили 2777 випадків COVID-19. 89 паџієнтів одужали, 83 померли.

За даними Університету Джонса Гопкінса, у США кількість хворих на коронавірус перевищила 542 тисячі, померло понад 21 тисяча людей. Загалом у світі вже 1 мільйон 827 тисячі інфікованих і понад 113 тисяч смертей.

- Президент Дональд Трамп уперше в історії країни запровадив режим стихійного лиха на всій території США.

- $\quad$ Під час Великоднього звернення, щяо транслювалось на Үоитиве, Папа Римський Франииск закликав світ не піддаватись страху, натомість об'єднатись у молитві“.

Then - 4 parts with their own hyperlinks: „Президент США Дональд Трамп і перша леді Меланія Трамп привітали американців з Великоднем“, „Ситуація з COVID-19 у CША викликає „обережний оптимізм в експертів, проте чи відкриється краӥна до 1 травня? “, „, У Чорногорії затримали митрополита за богослужіння під час режиму карантину“, „Американські ресторани почали торгувати у роздріб продуктами, щуоб зберегти бізнес “. Each text varies in size from one complex sentence to 3 paragraphs with repeated hyperlinks, at the end there is a block "Read more here" for a detailed acquaintance with the source of primary information and for the factuality and truthfulness of information.

The hyperlink ,More“ completes the creolized text.

Schematically this model can be represented in such a way:

\footnotetext{
${ }^{16} \mathrm{https} / / /$ ukrainian.voanews.com/a/american-weekend-news-overview/5251805.html (4th August 2020)

17 https://ukrainian.voanews.com/a/zelensky/5428272.html (4 ${ }^{\text {th }}$ August 2020)

${ }^{18}$ https://ukrainian.voanews.com/a/khronika-covid-12-kvitnia/5368994.html (4th August 2020)
} 


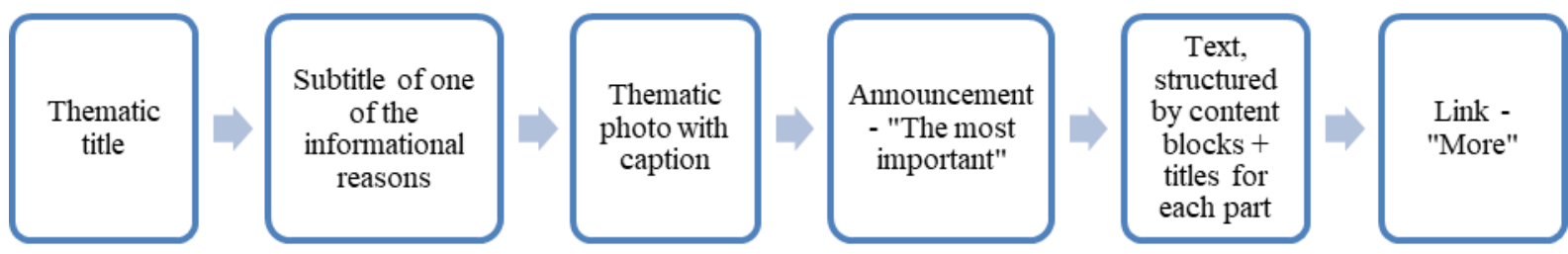

3. The review may have a clear hypergenre model. Because the media ,should be also framed within an ever-changing environment. It is where digital native media emerge, showing more or less balanced features of hybridisation between the older media logics, broadcasting and reception, and the new logics of circulation and negotiation. This scenario of changes calls for a review of digital journalism in native media, as it must face renewed challenges using audacious formulas, with the aim of fulfilling its tasks in the new social, political, and economic context of the network society“" (García-Orosa, López-García, Vázquez-Herrero, 2020, p. 7).

For example, „Головне про коронавірус. 16 квітня “19: title „Головне про коронавірус. 26 травня“, subtitle = first information „Міжнародний валютний фонд застерігає, щзо пандемія коронавірусу підштовхує світ до економічного спаду - небувалого упродовж кількох десятків років“.

Photo with caption „Французький авіаносець "Шарль де Голль", на якому у кількох сотень моряків виявили коронавірус“.

Structural part "The most important":

- $\quad$ МВФ прогнозуе, що за 2020 рік світова економіка скоротиться на $3 \%$ - це в 30 разів гірше часів фінансової кризи 2009 р.

- Президент США Дональд Трамп планує оголосити вказівки для штатів стосовно порядку скасування карантинних заходів.

ще на 3 тижні.

Від уряду Великої Британії очікують продовження всенаџіонального карантину

- Німеччина услід за деякими країнами Свропи з наступного тижня починає скасовувати окремі карантині обмеження “.

Then - separate structural parts with their own titles and video information are given:

„Кардіолог Юрій Дейчаківський - про роботу на передовій боротьби з пандемією коронавірусу. Інтерв'ю“

„Огляд новин у США: у Білому домі вирішують коли відкривати економіку; кількість безробітних зростає“"

„Час-Тайм. На передовій боротьби з пандемією - інтерв'ю з кардіологом“

At the end, as a separate structural part there is a screenshot of a tweet with statistics of diseases of health care workers and a reference to other VOA tweets.

The hyperlink "More" completes the creolized text.

Schematically this model can be represented in such a way:

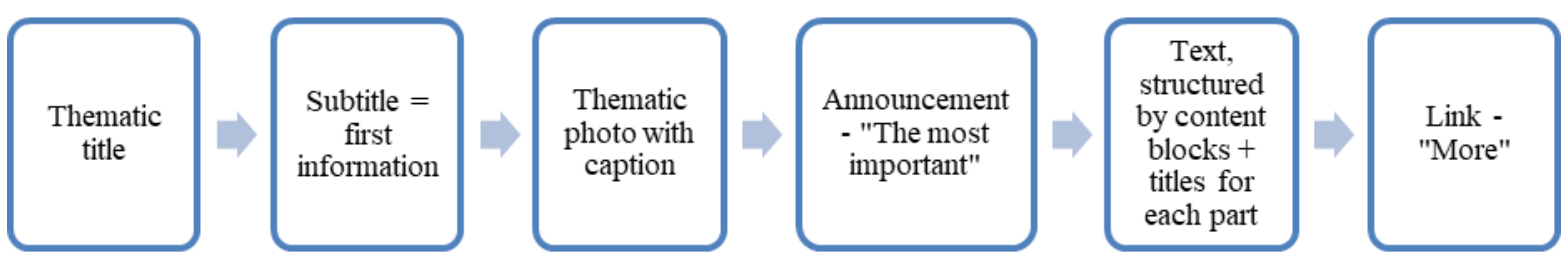

Radio Liberty Ukraine

The reviews of this media resource are mostly presented in text format with creolization (photos, hyperlinks to publications that have become a source of information, available in each text, on tweets, as well as in some texts - hyperlinks to other social networks). Genre models:

${ }^{19}$ https://ukrainian.voanews.com/a/khronika-covid-16-kvitnia/5374387.html (4 ${ }^{\text {th }}$ August 2020) 
1. The title-quote from one of the sources, for example: „Юрій Макаров: В Украйні досі не вироблений імунітет від ворожсої пропаганди“ (огляд преси)“20.

The lead paragraph that briefly outlines the information reason, for example: „Українська преса продовжує підбивати підсумки першого року перебування Володимира Зеленського на посаді президента. Як змінилась $і$ чи змінилась зовнішня та внутрішня політика Києва, чи можливий реванш і як Україна протистоїть російській пропаганді, - иі теми в центрі уваги тижневої преси “21, text, divided into parts graphically - with a horizontal line, authorship. There is no conclusion or generalization at the end of the text.

Schematically this model can be represented in such way:

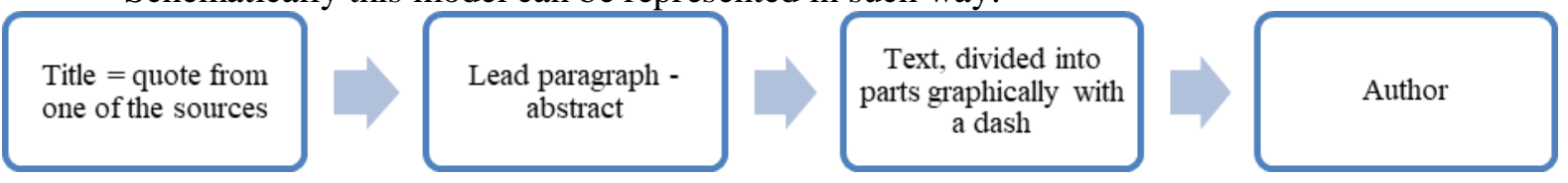

2. A slightly different model of press review is more common. Title-quote from one of the sources, for example: „„„Кадрові зміни будуть не лише в Кабміні, а й в Офісі президента“ Небоженко (огляд преси)“"22, „Війна $і$ День соборності. Украӥні потрібна єдність усіх українців - Гошуляк (огляд преси)“23, „Підхід до обміну полоненими треба змінити повністю-Асєєв (огляд преси) “24.

Three-four different thematic parts, divided only graphically - with a horizontal line. Creolization - photography, a hyperlink on the sources, mentioned in the text.

There is no generalization or final remark.

At the end there is an author's presentation.

Note that such a review is somewhat problematic for the recipient's interest and information retrieval, because only by looking at the text, reading individual fragments you can understand that thematically it is diverse, not devoted to one topic, marked in the title.

Schematically this model can be represented in such way: Title $=$ quote from one of the
sources
Text divided into parts graphically with a dash

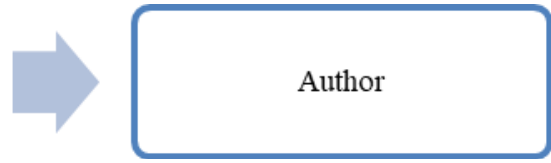

3. The title - informational reason / topic of the review, for example: „НАБУ розслідує держсавний тендер на захисні костюми для медиків - світова преса" 25 , „Скорочення фінансування культури та освіти впливає на здатність Украӥни захистити себе (західна npeca) ${ }^{\text {“26. }}$.

The lead paragraph in the form of content - at the beginning of the text the main topics of the review are presented, for example:

- $\quad$ „НАБУ розслідує державний тендер на захисні костюми для медиків, пиме в ексклюзивному матеріалі агентство Reuters

- $\quad$ Зеленський пережси імпічмент Трампа і грубо зупинив сподівання, підбиває підсумки першого року украӥнського президента на посаді журнал Foreign Policy

- Україна виявилася побічно причетною до торговельного скандалу в Польщі, інформують польські 3MI, зокрема видання Wprost“27.

\footnotetext{
${ }^{20}$ https://www.radiosvoboda.org/a/30631323.html (2 ${ }^{\text {nd }}$ August 2020)

${ }^{21} \mathrm{https} / / / \mathrm{www}$. radiosvoboda.org/a/30631323.html (2 $2^{\text {nd }}$ August 2020)

${ }^{22} \mathrm{https}$ ://www.radiosvoboda.org/a/30375265.html ( $2^{\text {nd }}$ August 2020)

${ }^{23}$ https://www.radiosvoboda.org/a/30389966.html (2 ${ }^{\text {nd }}$ August 2020)

${ }^{24} \mathrm{https} / / / \mathrm{www}$. radiosvoboda.org/a/30559945.html (2 ${ }^{\text {nd }}$ August 2020)

25 https://www.radiosvoboda.org/a/ohliad-presy/30636026.html ( $2^{\text {nd }}$ August 2020)

26 https://www.radiosvoboda.org/a/ohliad-zakhidoji-presy/30565434.html (1 ${ }^{\text {st }}$ August 2020)

27 https://www.radiosvoboda.org/a/ohliad-presy/30636026.html (1 ${ }^{\text {st }}$ August 2020)
} 
- „ІІспанський часопис Noticias de Gipuzkoa пише про поштовх до ухвалення реформістських законопроектів украӥнським парламентом, який Украйна отримала внаслідок кризи Covid-19.

- Нідерландське видання Аkkerwijzer повідомляс про готовність Украӥни заборонити експорт зернових в умовах почирення коронавірусу.

- $\quad$ Англомовне періодичне видання украӥнської діаспори у північній Америці Тhe Ukrainian Weekly публікує відкритого листа до керівництва Украӥни щцоо урізання коштів на діяльність украӥнських культурних та освітніх установ “28.

The text is not structured in separate parts. Not only photos were used for creolization, but also screenshots from tweets with the hyperlinks, as well as hyperlinks on the media resources, mentioned in the text. However, there is no final generalizing part.

At the end there is an author's presentation.

Schematically this model can be represented in such way:

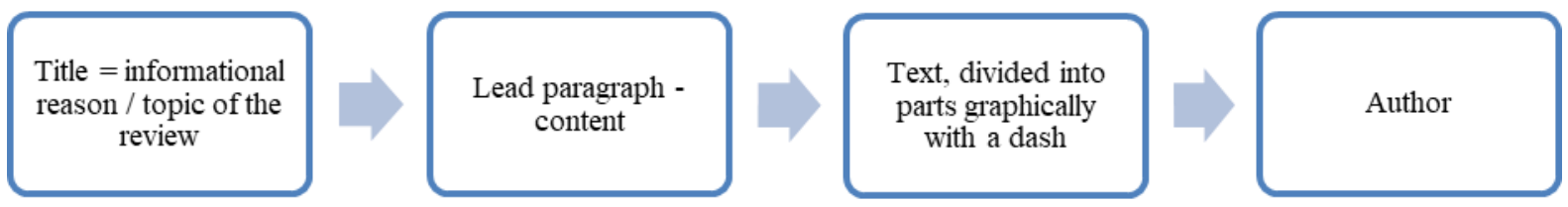

4. Thematic title - lead paragraph-summary - text + videocreolization - conclusion - author's presentation. Such as: „Несподіванки фіналу „Евробачення - 2020“ $~$ Go-A, КRUTЬ, КНАYAT, TVORCHI ${ }^{\text {29 }}$ - title.

„Фінал нацвідбору „Евробачення-2020“ таки не обійщовся без скандалу. Взагалі, умовно його можсна поділити на такі епізоди: несподівана перемога, неочікуване падіння $i$ скандал навколо. Але про все по порядку.

Впевнену перемогу здобув гурт $\boldsymbol{G o - A}:$ найвищий бал як від суддів, так і від глядачів. На „Свробаченні “ у Роттердамі буде представлена пісня повністю украӥнською мовою.

Радіо Свобода підготувало короткий огляд фіналу нацвідбору, який покаже те, чого неможливо побачити під час трансляиіi ${ }^{\text {‘30 }}$ - lead paragraph.

Then the actual text is given with quotes of the contestants, hyperlinks to the videos of their performances, comments on social networks.

Concluding part:

„Взагалі иьього року оиінки суддів і глядачів по більшості позицій збігалися.

Транслячія фіналу нацвідбору на „Свробачення-2020“ відбувалася на двох загальнонаціональних каналах: „СТБ“ та ,UА:Перший“.

„Свробачення-2020“ відбудеться 12, 14 і 16 травня 2020 року в Роттердамі в Нідерландах. Цього року фінансову підтримку переможиеві національного відбору під час підготовки, поӥздки й перебування на конкурсі в Нідерландах надає Суспільне мовлення. Витрати, пов'язані з кастингом і телевізійною частиною нацвідбору, взяв на себе телеканал ,CTБ ${ }^{\text {(31. }}$.

The presentation of the author of the text with creolization - photography, hyperlinks on pages in social networks.

Schematically this model can be represented in such a way:

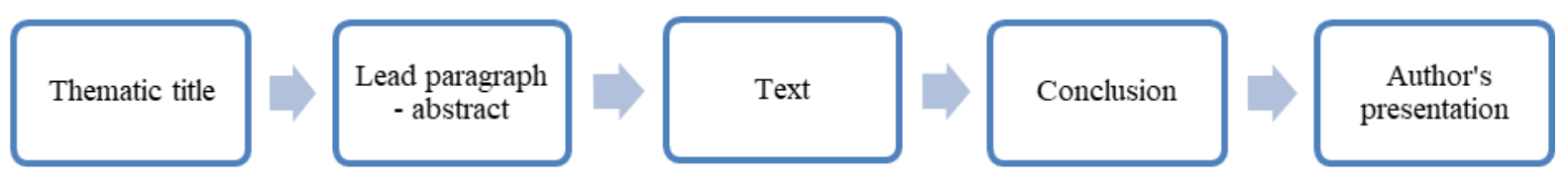

BBC NEWS Ukraine

\footnotetext{
${ }^{28} \mathrm{https}$ ://www.radiosvoboda.org/a/ohliad-zakhidoji-presy/30565434.html (1 ${ }^{\text {st }}$ August 2020)

${ }^{29} \mathrm{https}$ ://www.radiosvoboda.org/a/final-evrobachennya-go-a-krut-khayat-tvorchi/30450091.html (31 ${ }^{\text {st }}$ July 2020)

${ }^{30} \mathrm{https} / / / \mathrm{www}$. radiosvoboda.org/a/final-evrobachennya-go-a-krut-khayat-tvorchi/30450091.html (31 $\left.{ }^{\text {st }} \mathrm{July} 2020\right)$

${ }^{31}$ https://www.radiosvoboda.org/a/final-evrobachennya-go-a-krut-khayat-tvorchi/30450091.html (31 ${ }^{\text {st }}$ July 2020)
} 
The reviews, presented in this media resource, have a text format with creolization (photo images, hyperlinks to primary sources of information, video).

Genre models of cultural review:

1. The title that usually names one of the topics of the review, for example: „Продовження „Друзів“ під питанням. Культоголяд“љ2, „Чи писало ЦРУ пісню для Scorpions культогляд “33.

The lead paragraph that lists all thematic blocks of the text, for example:

„Чи буде продовження популярного ситкому "Друзі", про рожеве шампанське від Пітта і Джсолі та новий хіт від Леді Гага - читайте у свіжсму культогляді ${ }^{634}$.

„Хто написав пісню-легенду для Scorpions, як у Польщі знімають фільм Олега Сенцова, а фанати "Евробачення" вгамовують біль від скасування конкурсу - в нашому культогляді ${ }^{\text {(35. }}$.

The text is structured into separate parts, each of which has its own title, such as:

„Возз'єднання "Друзів" під питанням“, „Нічого особистого, просто бізнес“, „Леді Гага написала новий хіт?"з6.

„Хто написав Wind of Change - Scorpions чи ЦРУ?“, „Завершення „кінокарантину“ в Польщі““, „,Травень без „,Свробачення“",, ,ППаттісон проти накачаних колег“37. Each structural part is accompanied by thematic photographs and hyperlinks on the original sources of information.

There is no concluding part. The name of the author, who prepared the review, is given.

Schematically this model can be represented in such a way:

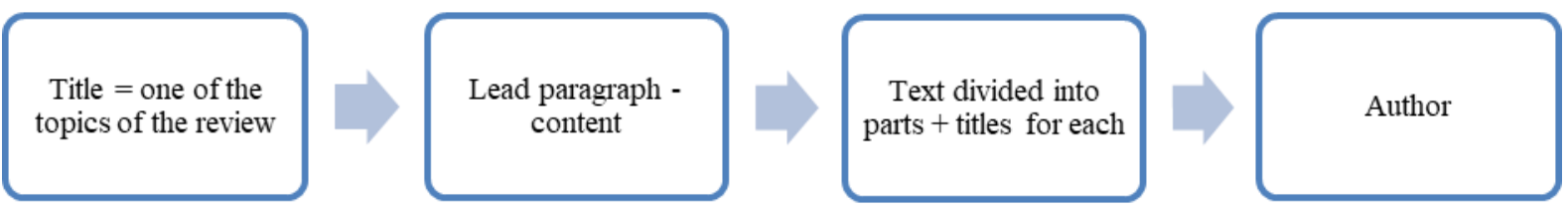

2. The title that usually names one of the topics of the review, for example: „Голівуд змінює привила для сексу в кіно. Культогляд “38, „Лікар носить Prada: як індустрія моди допомагає медикам, Культогляд “39.

The lead paragraph in the format of structured by topics annotation:

„У свіжому культогляді читайте про таке:

-

- Що буде иього року замість Свробачення

-

- Як віртуально потрапити до найкращих музеїв світу “40.

However, further in the text each thematic block will have its own title that does not coincide with the lead paragraph, for example: „Мода на допомогу“, „Евробачення: шоу триває“, „Місия в периому ряду“, „Віртуальна подорож“"41, therefore, we consider that such a lead paragraph has annotative nature.

The text is creolized by thematic photos and hyperlinks on other media resources, the information of which is used.

There is no generalizing or concluding part. The author, who prepared the review, is named.

Schematically this model can be represented in such a way:

\footnotetext{
${ }^{32}$ https://www.bbc.com/ukrainian/press-review-51248473 (5 $5^{\text {th }}$ August 2020)

33 https://www.bbc.com/ukrainian/press-review-52683589 (6 ${ }^{\text {th }}$ August 2020)

${ }^{34}$ https://www.bbc.com/ukrainian/press-review-51248473 (5 ${ }^{\text {th }}$ August 2020)

35 https://www.bbc.com/ukrainian/press-review-52683589 $6^{\text {th }}$ August 2020

36 https://www.bbc.com/ukrainian/press-review-51248473 (5 ${ }^{\text {th }}$ August 2020)

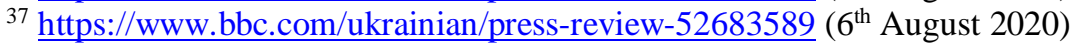

${ }^{38} \mathrm{https} / / / w w w . b b c . c o m / u k r a i n i a n / n e w s-51313952$ ( $7^{\text {th }}$ August 2020)

39 https://www.bbc.com/ukrainian/news-52157095 (7 $7^{\text {th }}$ August 2020)

40 https://www.bbc.com/ukrainian/news-52157095 (7 $7^{\text {th }}$ August 2020)

${ }^{41}$ https://www.bbc.com/ukrainian/news-52157095 (7 $7^{\text {th }}$ August 2020)
} 


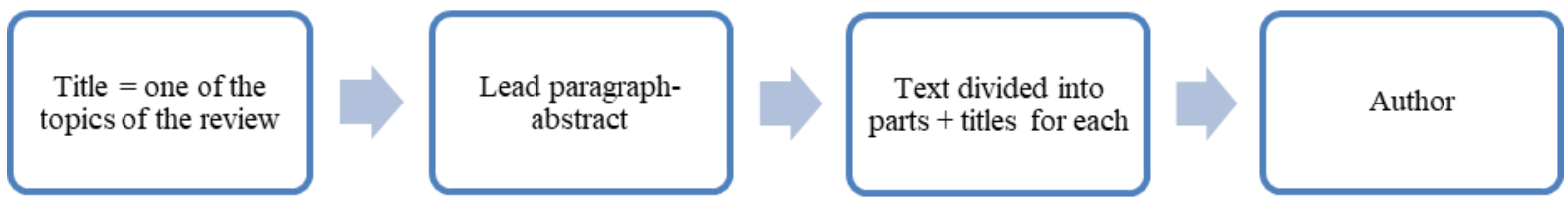

The media review has the following genre models:

1. Title, indicating the topic, for example: „Більще не комік? Західні ЗМI про рік Зеленського "42.

The lead-paragraph-summary, for example:

„Західні ЗМІ відзначають, щио через рік після вступу на посаду президента Володимир Зеленський відійшов від амплуа комедійного актора.

Іноземна преса звертає увагу на відмінності у порівнянні з першим пресмарафоном президента, а також зазначає, що в річницю свого президентства Зеленський знову опинився втягнутим в американські політичні розбірки““43.

The text, structured into thematic blocks with their own titles: „Складний рік“, „Плівки Байдена "44. In the text, the photos and hyperlink of the video of the press conference of President V. Zelensky are mounted thematically: „Що иікавого було на пресконферениії“ and „Цитати Зеленського: чим запам'яталася пресконферениія “45.

There is no conclusion / generalization. At the end the author, who prepared the review, is named.

Schematically this model can be represented in such a way:

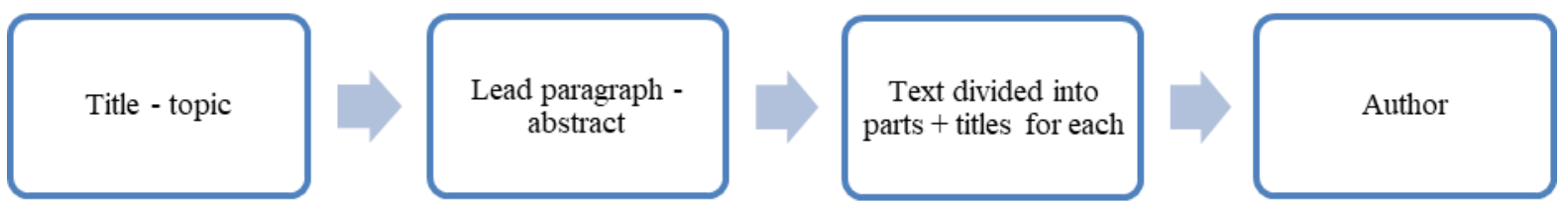

2. The title that reflects one of the subcontracting themes of the general theme: „Уому коронавірус частіше вбиває чоловіків, ніж жжінок - огляд $3 \mathbf{M I}^{\star 46}$, then the whole text is formed around various aspects, related to COVID-19.

The lead paragraph-annotation in the form of interrogative sentences, the answers on which the recipient will receive by reading the relevant parts of the review:

„У середу, 8 квітня, західна преса пише про таке:

- Чому коронавірус частіше вбиває чоловіків, ніж жінок

- Як Чехія, Австрія та Данія планують першими в Свропі послабити обмежувальні заходи

- Чи загрожує пандемія єдності Свросоюзу

- Чому навіть прихильники здорового способу життя почали віддавати перевагу шкідливій їжі під час карантину““7.

The main text is structured by semantically completed parts with separate titles for each that do not repeat the interrogative constructions in the lead paragraph: „, Чоловіки у більшій небезпеиi? “", „Послаблення карантину - чи не зарано? “, „, СС може „,потонути разом“,,, „Здоровий спосіб життя під загрозою “. In each part there are hyperlinks to primary sources of information.

There is no generalization or conclusion.

The text is creolized by thematic photos.

At the end the author, who prepared the review, is indicated.

Schematically this model can be represented in such a way:

\footnotetext{
42 https://www.bbc.com/ukrainian/press-review-52757051 ( $7^{\text {th }}$ August 2020)

43 https://www.bbc.com/ukrainian/press-review-52757051 ( $7^{\text {th }}$ August 2020)

${ }^{44} \mathrm{https}: / /$ www.bbc.com/ukrainian/press-review-52757051 ( $7^{\text {th }}$ August 2020)

45 https://www.bbc.com/ukrainian/press-review-52757051 ( $7^{\text {th }}$ August 2020)

46 https://www.bbc.com/ukrainian/press-review-52213996 (6 ${ }^{\text {th }}$ August 2020)

47 https://www.bbc.com/ukrainian/press-review-52213996 (6 $6^{\text {th }}$ August 2020)
} 


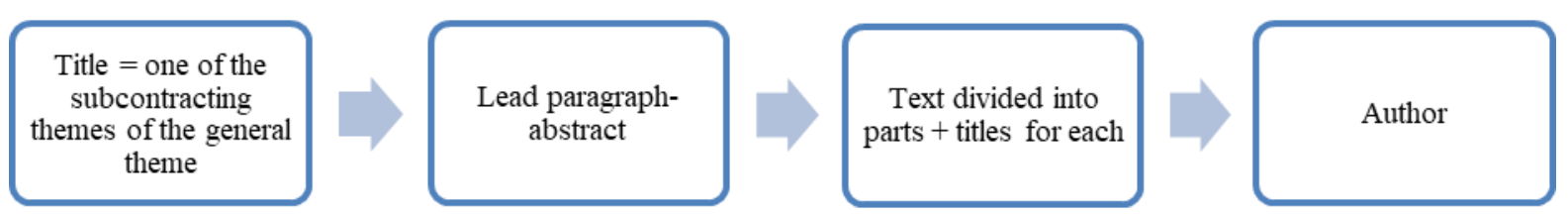

3. The title that names one of the review topics, for example: „Стрибок Британіï $y$ невідоме. Огляд ЗМI“48, „Чим загрожує збільшення грудей - огляд ЗМI“49, „Карантин можна лінитися? Огляд 3 МІ“50.

The lead paragraph in the form of an annotation, formed with the help of interrogative sentences, the answers to which are given below in the text, for example:

„Західні ЗМІ 6 лютого висвітлюють такі теми:

- Чим загрожує збільшення грудей

- Як Гаррі та Меган насолоджуються життям в Канадi

- Чи допоможе нова дієта Тайсону Ф'юрі побити Деонтея Вайлдера ${ }^{51}$.

„Теми огляду західної преси у четвер, 9 квітня:

- Чому не варто ставити собі амбітні иілі на карантин

- Чи може онлайн-навчання бути не менш ефективним за традиційне

- Чому завершення карантину в Ухані не означає повернення до нормального

життя

- Чи обмежуватиме Украӥна експорт зерна “52.

The text is divided into separate content blocks with their own titles, such as:

„,Страждання від імпалантів“, ,П Полегшення “, „Різноманітне меню “53.

„Що обрати - продуктивність чи лінощі?“, „Онлайн-заняття: ефективно, але не дуже весело “, „Драконівські“" правила так і не скасували“, ,, Чи буде дефіиит? “"54.

As we can see, the titles of the structural parts do not repeat the questions from the lead paragraph. The text is creolized by thematic photographs and hyperlinks to primary sources of information.

There is no final part. At the end the author, who prepared the review, is named.

Schematically this model can be represented in such a way:

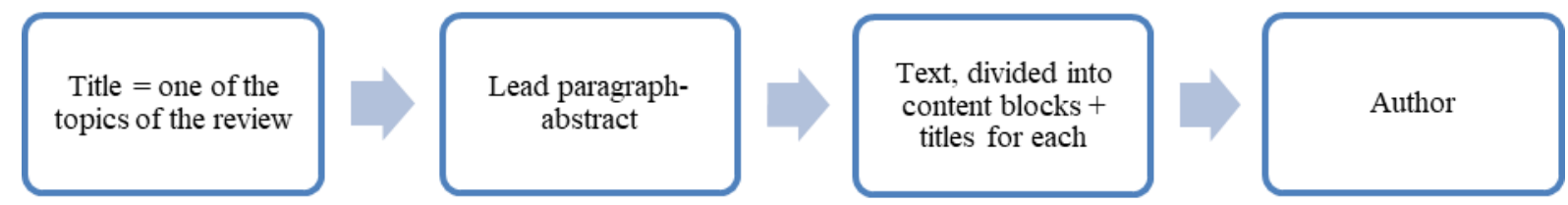

Conclusion. Modern professional interpretation of media content generates a number of discussions related to the functional identification of the review genre. Its analytical nature, reflected in the commented traditional aspects of the interpretation of the review articles and materials, nowadays is reduced to the dominance of information nature and „necessary“ emphasis on „important" current meanings. When the mass audience receives concretized or more often generalized information about the event, factually saturated with deliberately selected material, it leads to the special tone of the assessment.

Therefore, we observe the modification of the review genre model in accordance with the specifics of information media resources and the needs of the modern recipient quickly to receive large amounts of information in condensed form, processed for perception without additional effort

\footnotetext{
${ }^{48}$ https://www.bbc.com/ukrainian/press-review-51358844 ( ${ }^{\text {th }}$ August 2020)

49 https://www.bbc.com/ukrainian/press-review-51402085 ( ${ }^{\text {th }}$ August 2020)

${ }^{50}$ https://www.bbc.com/ukrainian/press-review-52229089 ( $7^{\text {th }}$ August 2020)

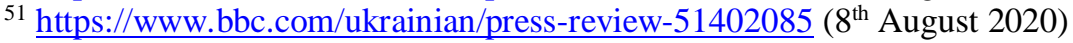

52 https://www.bbc.com/ukrainian/press-review-52229089 ( $7^{\text {th }}$ August 2020)

53 https://www.bbc.com/ukrainian/press-review-51402085 (8 ${ }^{\text {th }}$ August 2020)

${ }^{54}$ https://www.bbc.com/ukrainian/press-review-52229089 $\left(7^{\text {th }}\right.$ August 2020)
} 
for independent selection and decoding of information. This is due to the fact that "media constitute a socially important area of activity whose language use can differ from the way in which language is used in other domains" (Perrin, 2013, p. 60). As a result, the rather constant (in particular, for the context of fiction) nature of the genre category in modern mass media is transformed into a dynamic form of informing the mass audience, adaptable to the communicative needs of participants in social communication. And therefore, “a set of media genre variants includes: „canonical genres (the most persistent and decisive for species identity), alternation genres, which are primarily the result of a specific set of transformations of the canonical pattern (structural changes usually begin with transformations), adaptive genres, typical for a given species, ways of assimilating conventions of other species" (Woitak, 2006, p. 31).

That is why in most of the analyzed media we observe a similar general model with communicative varieties: title with topic / topics (possibly in the form of a quote from one of the primary sources of information) - lead paragraph that specifies the topics of different types (review, lead paragraph-annotation), - creolized text, structured by thematic blocks with their own titles, presentation of the author, who prepared the review. We also observe the absence of verbalized transitions and connection between thematic parts and the final part, which suggests that the modern review, disseminated in the information media, is changing, becoming more informative, losing analyticity in the classical sense. However, analyticalness remains in the selection and processing of primary information, quotations, links, etc.

Schematically this model can be represented in such a way:

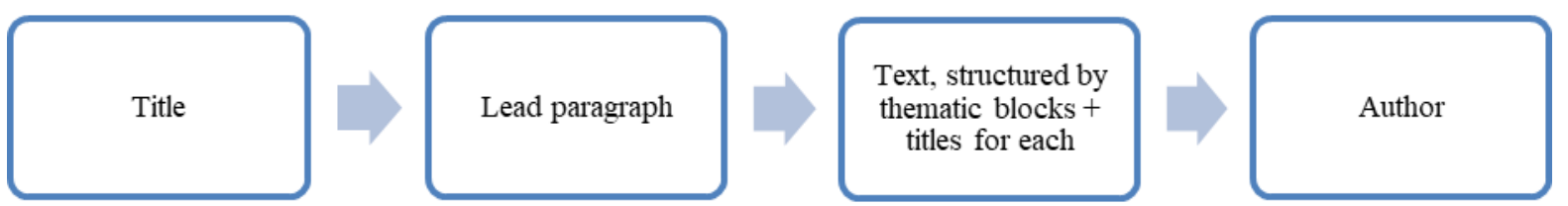

It is important to distinguish the reviews of Radio Free Europe / Radio Liberty, because some of them contain a significant analytical component, expressed both explicitly and implicitly through the verbalization of the author's assessment. They are characterized by the structure of the whole text with only a graphical division into thematic and semantic blocks, but a significant drawback is the lack of a lead paragraph or a more detailed representative title with a reflection of all the topics, reflected in the text. Many recipients may not be interested in just one of the topics in the title and may not read the text at all. Thus, the assessment of the review can be defined as an implicit, nonverbal category that manifests itself at the level of information "mounting" from different sources in the context of simulating the analytical resource of the review text and context. It creates a permanent dynamization of the review genre nature and determines the prospects of its research analysis - in particular in the linguistic and cultural discourse that deepens the medialinguistic and genre subjectivity of the professional interpretation of modern mass media.

\section{BIBLIOGRAPHY}

Мак-Квейл, Д. (2010)

Седов, К.Ф. (2012)

Сухобокова, О. (2009)
Теорія масової комунікації, пер. О. Возьна, Львів: Літопис. (McQuail, $D$. Teoriya masovoyi komunikatsiyi. Lviv: Litopys).

Языкознание. Речеведение. Генристика // „Bonpocbl психолингвистики“, № 1 (5), С. 216. (Sedov, K.F. Yazykoznaniye. Rechevedeniye. Genristika. // Voprosy psiholingvistiki, vol. 1 (5), S. 210 223).

Український відділ радіостанції „Голос Америки“: до 60-річчя від створення // „Вісник Київського національного університету імені Tараса Шевченка. Історія“, № 97, С. 60 - 63. (Sukhobokova, O. Ukrainskyi viddil radiostantsii "Holos Ameryky": do 60-richchia vid stvorennia // Visnyk Kyivskoho natsionalnoho universytetu imeni Tarasa Shevchenka. Istoriia, vol. 97, pp. 60-63).

Шевченко, Л.І. \& Дергач, Д.В. Медіалінгвістика. Словник термінів і понять, Київ 2014, С. 128 \& Сизонов, Д. Ю. (2014) 129. (Shevchenko L.I., Dergach D.V., Syzonov D.Y. Medialingvistyka slovnyk terminiv i poniat. Kyiv : Kyiv university, pp. 128 -129) 
Book reviews

Cambridge dictionary

Collins dictionary

Fairclough, N. (1995)

Fleenor, J W. (2004)

García-Orosa, B. \& LópezGarcía, X. \& Vázquez-

Herrero, J. (2020)

Hoggart, R. (1997)

Kozhakhmetova,

Ospanova. Z. \& Mussatayeva, M.

\& Bissenbayeva, Z. (2020)

Lexico dictionary (powered by

Oxford)

Mass media review articles

Perrin, D. (2013)

Samraj, B. (2016)

Van Dijk, Teun A. (1995)

Ventres, W. \& Morrow, C. (2009)

Woitak, M. (2006) https://writingcenter.unc.edu/tips-and-tools/book-reviews (05.08.2020)

https://dictionary.cambridge.org/ru/словарь/английский/review

(03.08.2020)

https://www.collinsdictionary.com/dictionary/english/review

(03.08.2020)

Media Discourse. London: Edward Arnold, P. 20-34.

Book reviewing as an important scholarly activity // Personnel Psychology, vol. 57 (4), pp. 1036 - 1037. https://doi.org/10.1111/j.17446570.2004.014_1.x

Journalism in Digital Native Media: Beyond Technological Determinism

// Media and Communication, vol 8, n. 2, pp. 5 - 15. https://doi.org/10.17645/mac.v8i2.2702.

Reviewers and reviewing // Society, vol. 2, pp. $64-67$.

\& Axiological concepts of journalistic texts (lingua-stylistic analysis) //

XLinguae, vol. 13, n. 2, pp. 225 - 234.

https://doi.org/10.18355/XL.2020.13.02.19.

https://www.lexico.com/definition/review (03.08.2020).

https://www.omicsonline.org/mass-media-review-articles.php

(01.08.2020).

Investigating language and the media: The case of newswriting // AILA Review, vol. 26, n. 1, pp. 57-78. https://doi.org/10.1075/aila.26.05per.

Discourse structure and variation in manuscript reviews: Implications for genre categorization // English for Specific Purposes, vol. 42, pp. 76 - 88. https://doi.org/10.1016/j.esp.2015.12.003.

The Mass Media Today: Discourses of Domination or Diversity? // Javnost - The Public, vol. 2, n. 2, pp. 27 - 45. https://doi.org/10.1080/13183222.1995.11008592.

C. The Joy of Reviewing: A Short Guide to Writing Book and Media Reviews // Family medicine, vol. July-August, pp. 492 - 493.

Analiza gatunków prazowych. Zręby teorii i elementy dydaktyki // Media, Kultura, Społeczeństwo. Vol. 1, pp. $29-39$. 